DOI: https://doi.org/10.47405/mjssh.v6i8.935

\begin{tabular}{|c|c|}
\hline 4 & Malaysian Journal of Social Sciences and Humanities (MJSSH) \\
\hline $\begin{array}{l}\text { Malaysian Juoural of } \\
\text { Social ccciecces and }\end{array}$ & Volume 6, Issue 8, August 2021 \\
\hline (MJ-sSH) & e-ISSN : 2504-8562 \\
\hline & $\begin{array}{l}\text { Journal home page: } \\
\text { www.msocialsciences.com }\end{array}$ \\
\hline
\end{tabular}

\title{
Kapal Wap, Laluan Maritim dan Penghantaran Buruh Cina dan Jawa ke Borneo Utara, 1881-1941
}

\author{
Maureen De Silva ${ }^{1}$, Nursyazwani Binti Edinin ${ }^{1}$ \\ ${ }^{1}$ Fakulti Sains Sosial dan Kemanusiaan, Universiti Malaysia Sabah (UMS) \\ Correspondence: Maureen De Silva (maureend@ums.edu.my)
}

\begin{abstract}
Abstrak
Perkembangan teknologi maritim telah memberi impak signifikan kepada Asia Tenggara. Sebelum kapal wap diperkenalkan, pengembara dan pedagang bergantung kepada kapal layar untuk perjalanan jarak jauh dan perjalanan tersebut menjadi sukar dan membahayakan kerana keadaan cuaca yang tidak dapat diramalkan, terutama semasa perubahan monsun dan angin. Transformasi radikal industri perkapalan yakni dari penggunaan kapal layar kepada kapal wap berjalan seiring dengan kemuncak Revolusi Perindustrian di Eropah, yang menyaksikan perkembangan bukan sahaja perdagangan tetapi juga perluasan wilayah di bawah kawalan Eropah pada era imperialism baru. Pentadbiran Syarikat Borneo Utara British (SBUB) dari tahun 1881 hingga tahun 1941 adalah contoh perluasan wilayah dan dominasi ekonomi Eropah yang menyaksikan kedatangan buruh asing terutama buruh Cina dan Jawa ke Borneo Utara dengan menggunakan kapal wap melalui beberapa laluan maritim untuk memenuhi tuntutan ekonomi Borneo Utara. Berdasarkan penggunaan sumber primer (laporan tahunan, surat dan akhbar kolonial), dan sumber kedua, artikel ini bertujuan untuk mengenal pasti korelasi antara kegiatan manusia dalam bentuk migrasi tenaga buruh, dan kondisi serta persekitaran maritim terutama dalam penggunaan kapal wap dan laluan maritim. Kajian ini mendapati bahawa terdapat hubung kait antara kedatangan buruh asing dengan aspek maritim di mana isu-isu yang berkaitan dengan laluan maritim, jarak dan jangka waktu perjalanan, kos yang ditanggung, pemilikan kapal, persaingan kuasa dan dasar perlindungan, serta kebersihan atas kapal merupakan antara faktor-faktor dominan yang mempengaruhi penghantaran buruh Cina dan Jawa ke Borneo Utara.
\end{abstract}

Kata kunci: kapal wap, laluan maritim, buruh Cina, buruh Jawa, Borneo Utara

\section{Steamships, Maritime Routes and the Shipment of Chinese and Javanese Labourers to North Borneo, 1881-1941}

\begin{abstract}
The development of maritime technology impacted Southeast Asia in ways beyond imagination. Prior to the introduction of steamship, travellers and merchants depended on sailing ship when making long distance travelling and journeys could be ardous due to unpredictable weather conditions, particularly in the changing of monsoons and winds. The radical transformation of the shipping industry from sailing ship to steamship ran parallel with the peak of the Industrial Revolution in Europe, which witnessed an expansion of not only commerce but also territories under European control during the era of new imperliasm. It was during this period when the British North Borneo Company (BNBC) obtained a royal charter in 1881 to govern North Borneo, and thus began the rapid growth of economics of scale which required the importation of foreign labour. Thousands of Chinese and
\end{abstract}


Javanese labourers arrived by steamships via various maritime routes to cater to the demands of largescale economy in the territory. By utilsing mostly primary sources in the form of colonial office records (annual reports, correspondence and colonial newspaper) and secondary sources, the study hopes to identify the correlation between human activities in the form of labour migration, and the composition and condition of maritime environments particularly in the usage of steamships and waterways. This study reveals that there is a correlation between the arrival of foreign labourers to maritime aspect whereby issues pertaining to maritime routes, distance and the duration of the journey involved, overhead costs, ownership of vessels, big power rivalry and protectionism, and finally hygiene on board of steamships were dominant factors in influencing the shipment of Chinese and Javanese labourers in British North Borneo.

Keywords: steamships, maritime routes, Chinese labourers, Javanese labourers, North Borneo

\section{Pengenalan}

Perkembangan teknologi maritim telah memberi impak signifikan kepada Asia Tenggara. Transformasi radikal industri perkapalan dari penggunaan kapal layar kepada kapal wap sejajar dengan kemuncak Revolusi Perindustrian di Eropah pada abad ke-19. Pembukaan Terusan Suez pada tahun 1869 telah menyaksikan bukan sahaja perkembangan perdagangan dan perluasan kuasa Eropah melalui penjajahan era imperialisme baru malah perkembangan dalam dunia pelayaran. Kuasa-kuasa kolonial Eropah seperti British, Perancis dan Belanda masing-masing telah mengukuhkan dominasi politik dan ekonomi mereka di Asia Tenggara apabila berjaya menguasai beberapa koloni seperti Burma, Tanah Melayu, Borneo Utara, Sarawak dan Brunei bagi British, Vietnam, Kemboja dan Laos dikuasai oleh Perancis dan kepulauan Indonesia dikuasai Belanda. Pentadbiran di Filipina pula telah bertukar dari sebuah kuasa Eropah (Sepanyol) kepada kuasa Amerika (Amerika Syarikat) pada akhir abad ke-19.

Bagi Borneo Utara, penguasaan kuasa Eropah telah dimanifestasikan melalui pentadbiran Syarikat Berpiagam Borneo Utara (SBUB) bermula dari tahun 1881 sehingga tahun 1941 apabila agenda utamanya adalah untuk mewujudkan pentadbiran dan mengeksploitasi ekonomi wilayah tersebut. Antara yang telah dilakukan oleh SBUB adalah menyediakan pelbagai insentif yang menarik golongan pelabur untuk datang melabur ke Borneo Utara dan mengusahakan ekonomi berskala besar. Sektor pembalakan, pertanian dan perladangan telah dibangunkan namun cabaran paling utama yang dihadapi oleh pemerintah SBUB ketika itu adalah bekalan buruh yang tidak mencukupi untuk bekerja dalam sektor-sektor tersebut. Sehubungan dengan itu, bagi mengatasi masalah tersebut pihak SBUB telah membawa masuk buruh Cina dan buruh Jawa. Buruh-buruh ini telah dibawa menggunakan kapal wap dan bergerak dari pelbagai pelabuhan, melalui beberapa laluan maritim dan tiba di Borneo Utara untuk memenuhi tuntutan ekonomi wilayah tersebut. Justeru, artikel ini bertujuan untuk mengkaji hubung kait di antara kapal wap, laluan maritim dan perburuhan di Borneo Utara dari tahun 1881-1941. Secara spesifiknya, ia cuba menganalisis hubungan antara kegiatan manusia dalam bentuk migrasi tenaga buruh Cina dan Jawa, dan komposisi serta persekitaran maritim terutamanya dalam penggunaan kapal wap dan laluan maritim dalam mengangkut buruh-buruh ini.

Artikel ini merupakan satu analisis sejarah yang menggunakan sumber-sumber primer dan sekunder. Antara sumber yang diperoleh dan digunakan dalam kajian ini ialah seperti dokumen, surat rasmi, laporan tahunan British dan Belanda dan akhbar (British North Borneo Herald, North Borneo Central Archive, Colonial Official Records). Penulisan ini akan disokong menggunakan sumber sekunder.

\section{Perkapalan, Laluan Maritim dan Aktiviti Perdagangan di Borneo Utara}

Revolusi pengangkutan maritim bermula ketika manusia mula memanfaatkan ciri-ciri persekitaran semula jadi untuk mengangkut penumpang dan kargo dari satu tempat ke tempat lain dan mula mencari cara untuk menjadikan pengangkutan lebih murah, lebih cepat dan lebih efisien. Melalui peredaran 
masa, perubahan bidang teknologi telah membawa kemajuan kepada aspek pengangkutan di mana penciptaan mesin secara efektifnya telah menguasai teknologi pembuatan kapal ketika itu. Manusia boleh melakukan perjalanan ke mana sahaja di dunia dengan mudah dengan menggunakan kapal yang boleh mengangkut penumpang, bahan mentah dan produk dengan murah di pasaran global.

Sebelum kapal wap diperkenalkan, pengembara dan pedagang bergantung kepada kapal layar yang memerlukan kuasa angin untuk menggerakkannya. Untuk perjalanan jarak jauh, perjalanan menjadi sukar dan membahayakan kerana keadaan cuaca yang tidak menentu, terutama dalam perubahan monsun dan angin. Penciptaan enjin wap yang dimuatkan dalam kapal telah memberi impak besar dalam perkembangan ketamadunan manusia. Kapal wap (steamer) yang menggunakan arang batu sebagai bahan bakar bagi menjana tenaga untuk menggerakkan kapal mempunyai kelajuan yang lebih pantas dan dapat bergerak dengan lebih jauh dengan risiko bahaya yang lebih kecil berbanding dengan kapal layar. Kapal wap ini, dengan kapasiti muatan yang lebih besar merupakan suatu yang tipikal dalam revolusi pengangkutan yang berlaku pada abad ke-19 (Becker, 2010:249).

Perkembangan teknologi ini, selain daripada perkembangan revolusi perindustrian di Eropah dan pembukaan Terusan Suez pada tahun 1869, telah menjadi pemangkin kepada perluasan kuasa Eropah di rantau Asia Tenggara semasa era imperialisme baru pada pertengahan kedua abad ke-19. Pembukaan Terusan Suez telah mendekatkan lagi Eropah dengan Asia, dan telah mewujudkan laluan perdagangan baru dan amat kuat, yang boleh dilalui oleh kapal wap (Page \& Sonnenburg, 2003:575). Kemasukan kuasa kolonial Eropah seperti British, Belanda, dan Perancis telah memberi impak besar kepada perkembangan kegiatan maritim di Asia Tenggara dengan kemasukan kapal wap yang bukan sahaja membawa kepada penaklukan fizikal entiti politi di rantau ini tetapi ia juga telah mencetuskan perkembangan aktiviti perkapalan dan perdagangan yang besar, dengan jaringan kawasan yang lebih ekstensif.

Kapal-kapal wap milik syarikat perkapalan British, Belanda, Jerman, dan Jepun mula berulang alik di laluan maritim yang menghubungkan pelabuhan-pelabuhan Eropah, Asia-Pasifik dan Amerika. Di rantau Asia Pasifik misalnya, kapal-kapal yang mendominasi adalah dari Blue Funnel Line, China Navigation Company, Straits Steamship Company, Rotterdam Llyod Line, Stoomvaart Maatschappij Nederland, Koninklijke Paketvaart Maatschappij, Nord Deutscher Lloyd Steamship Company, Eastern and Australian Steam Navigation Company, Oceanic Steamship Company, Australian Steamship Company dan Indo-China Steam Navigation Company. Syarikat induk utama yang memiliki syarikat perkapalan ini termasuklah Alfred Holt and Co., Butterfield \& Swire Co., China Borneo Company, Mssrs Mansfield, Boogardt and Co., Messrs. Behn, Meyer \& Co dan Messrs. Jardine Matheson \&Co. Kapal wap akan beroperasi dengan jadual tetap dalam perdagangan tertentu dan menguasai lalu lintas laut, pesisir dan sungai. Untuk meregulasikan persaingan antara mereka, mereka akan bersidang dan memeterai perjanjian agar dapat memberi kebaikan dan keuntungan kepada pihak-pihak yang terlibat (Becker, 2010).

Syarikat-syarikat perkapalan ini mempunyai ibu pejabat di bandar-bandar pelabuhan utama seperti Singapura, Hong Kong dan juga Shanghai. Bandar-bandar pelabuhan ini akan berkembang menjadi pusat persinggahan kapal-kapal yang berulang-alik dari satu kawasan ke kawasan yang lain, termasuk melibatkan Borneo Utara. Menjelang tahun 1890 misalnya, sebanyak 2,989,059 tan perkapalan (yang mewakili 3646 kapal) menggunakan pelabuhan Singapura setiap tahun (Tregonning, 1965:227). Jaringan hubungan yang meluas di antara Singapura-Borneo Utara-Hong Kong menyebabkan ada syarikat perkapalan yang membuka cawangan mereka di Borneo Utara, yakni di Sandakan, untuk memudahkan operasi dan aktiviti maritim mereka. Ini termasuklah Messrs. Butterfield \& Swire Co. (1883-1941), China Borneo Company (1888-1920), Mssrs. Mansfield, Boogardt and Co. (1883-1941), Messrs. Behn, Meyer \& Co (1888-1941) dan Sabah Steamship Company (1894-1941).

Adanya syarikat perkapalan dan kapal-kapal wap mengangkut kargo dan penumpang yang melalui laluan maritim di persekitaran Borneo Utara telah membawa kepada jaringan komunikasi yang semakin luas yang menghubungkan Borneo Utara dengan dunia luar. Laluan maritim yang paling utama adalah di antara Borneo Utara dan Singapura, dengan jadual berkala lebih kurang 3 kali seminggu. Perjalanan dari Singapura ke Jesselton (Borneo Utara) akan mengambil masa lima hari. 
Rekod pada tahun 1883 menunjukkan bahawa terdapat tiga kapal wap utama yang mempunyai jadual tetap pergerakan pergi-balik Singapura-Borneo Utara iaitu S.S. Hong Ann, S.S. Banca dan S.S. Borneo (BNBH, 1 Mac 1883). Pada tahun 1898, dilaporkan kapal-kapal milik Nord Deutscher Lloyd Steamship Company mendominasi laluan maritim Singapura - Borneo Utara dengan tiga kapal wap beroperasi secara berkala (S.S Ranee, S.S. Banjermassin dan S.S.Hecuba), jadual pengoperasian diselaraskan dengan jadual pergi-balik kapal-kapal membawa surat (Lovegrove, 1912:552; BNBH 1 Januari 1898:13).

Bermula abad ke-20 pula, kapal-kapal wap The Straits Steamship Company (SSC) yang beribu pejabat di Singapura telah merancakkan lagi aktiviti maritim di antara Singapura dan Borneo Utara. SSC mengekalkan perkhidmatan mingguan yang kerap di antara Singapura dan pelabuhan-pelabuhan Borneo Utara dengan kapal-kapal seperti S.S. Marudu, S.S. Darvel dan S.S. Kajang. Kapal-kapal ini akan buat persinggahan di pelabuhan-pelabuhan Kuching dan Miri di Sarawak, dan Labuan, Jesselton, Kudat dan Sandakan di Borneo Utara. Ada kalanya kapal SSC akan berhenti di Jesselton sahaja dan kembali ke Singapura selepas itu. Kadang kala dari Jesselton kapal wap SSC akan bergerak ke Kudat selama 9 jam perjalanan, dan dari Kudat ke Sandakan pula akan mengambil masa di antara 12 hingga $15 \mathrm{jam}$.

Borneo Utara juga dihubungkan dengan pelbagai destinasi lain seperti Hong Kong, Australia dan Amerika Syarikat. Kapal-kapal wap yang dimiliki oleh Eastern Australian Steam Navigation Company dan Adelaide Steamship Company misalnya, beroperasi dalam laluan maritim di antara Port Darwin (Australia) dengan Borneo Utara. Syarikat perkapalan ini juga beroperasi di antara Australia dengan Hong Kong dengan Borneo Utara menjadi pelabuhan persinggahan. Kadang kala persinggahan di Borneo Utara ini tidaklah dijadualkan. Terdapat insiden di mana kapal-kapal wap akan menyimpang jauh dari laluan asal untuk singgah di pelabuhan Borneo Utara (Sandakan). Misalnya, Captain C. Griffin dari S.S. Ranee yang menjalankan perdagangan di jalur perdagangan di antara Hong Kong dan Australia kadang kala akan melakukan penyimpangan ke pelabuhan Sandakan dan akan mengambil masa lebih enam jam perjalanan tambahan. Jarak penyimpangan kapal wap ini adalah di antara 150 hingga 300 batu bergantung kepada laluan maritim yang digunakan (BNBH, 1 Mei 1889:148).

Bagi menghubungkan kawasan di Borneo Utara pula, Sabah Steamship Company Limited merupakan syarikat perkapalan yang diwujudkan pada tahun 1894 untuk memberi perkhidmatan pengangkutan di antara pelabuhan-pelabuhan Borneo Utara. Antara kapal milik Sabah Steamship Company yang beroperasi adalah S.S. Kinabalu (429 tan) dan S.S. Klias (210). Kapal-kapal ini akan bergerak dari Sandakan menuju ke Lahad Datu, Semporna dan Tawau di pantai timur. Kapal-kapal Sabah Steamship Company turut akan membawa muatan kargo dan penumpang ke pantai barat dan akan melalui pelabuhan Kudat, Usukan, Jesselton dan Labuan (Lovegrove, 1912:552).

Pengoperasian kapal-kapal wap melibatkan Borneo Utara bukan setakat melicinkan urusan pentadbiran kerajaan SBUB dengan kawasan lain tetapi ia juga telah menjadi nadi penggerak kepada perkembangan perdagangan komersial di Borneo Utara dan hubungannya dengan dunia luar. Ada syarikat perkapalan yang mempunyai kontrak untuk mengangkut sumber hasil Borneo Utara atau penumpang dari Borneo Utara ke destinasi luar. Kapal-kapal wap milik Butterfield \& Swire Co. seperti Loong Mon misalnya, mengangkut 200 tan kayu balak dari pelabuhan Sandakan ke Hong Kong, dan kapal penumpangnya S.S. Hankow dipercayai merupakan antara kapal penumpang yang terbesar yang pernah beroperasi di Borneo Utara di antara laluan Sandakan dengan Labuan ke Shanghai dan Hong Kong (BNBH, 15 Februari 1886; BNBH, 17 April 1886). Rekod juga menunjukkan bahawa pada tahun 1898 perdagangan kayu balak dengan Hong Kong turut dijalankan menggunakan sebuah kapal North German Lyold dan sebuah lagi kapal British (Lovegrove, 1912:552). Kapal-kapal wap dalam laluan maritim Australia - Hong Kong turut berlabuh di pelabuhan Sandakan, Labuan dan Kudat untuk mengambil hasil kayu balak, tembakau dan juga penumpang dari Borneo Utara ke Australia (BNBH, 4 Feb 1884). Kapal-kapal wap ini mempunyai kontrak untuk mengangkut tembakau, kayu balak dari estet-estet di Teluk Marudu, Kudat, Sg. Kinabatangan dan Teluk Darvel untuk penghantaran dari Borneo Utara ke Australia dan Hong Kong. Selain itu, kapal S.S. Ventura di bawah Oceanic Steamship Company berperanan mengangkut penumpang dan hasil lada hitam, tembakau, buah pala, kayu balak, kopra ke Amerika Syarikat dari Borneo Utara (BNBH, 10 Disember 1887). 
Perkembangan perkapalan dan perluasan laluan maritim, sejajar dengan perkembangan sektor ekonomi berskala besar semasa era imperialisme baru yang melibatkan industri perladangan dan pembalakan di Borneo Utara, bukan sahaja telah mengikat Borneo Utara kepada sistem ekonomi global tetapi ia juga telah memperluaskan capaian sumber tenaga buruh di antara Borneo Utara dengan dunia luar. Pembukaan sektor ekonomi kapitalis telah menyaksikan pengimportan tenaga buruh luar, terutamanya buruh Cina dan buruh Jawa, untuk mengisi kekosongan yang tidak mahu atau tidak dapat dipenuhi oleh penduduk tempatan. Buruh-buruh ini akan diangkut menggunakan kapal-kapal wap yang dimiliki oleh pelbagai syarikat perkapalan seperti yang dijelaskan di atas, melalui laluan maritim yang pelbagai dan tertakluk kepada pelbagai undang-undang dan peraturan.

\section{Pengangkutan Buruh Asing ke Borneo Utara Melalui Laluan Maritim}

\section{Pengangkutan Buruh Cina}

Kehadiran orang Cina di Borneo Utara sudah dikesan sejak sebelum era pentadbiran Syarikat Borneo Utara British (SBUB) lagi. Pada tahun 1858, Spencer St John, seorang pengembara Inggeris, ada menyebut tentang penduduk peribumi yang lancar berbahasa Hokkien dan dipercayai merupakan waris kepada migran Cina yang datang dari Singapura. Selain itu, Danny Wong Tze-Ken (1999) turut menyatakan kehadiran orang Cina Hokkien dan Teochiu dalam jumlah yang ramai menjalankan perniagaan di Borneo Utara pada waktu itu. Peranan orang Cina sebagai buruh juga telah dikesan sejak awal lagi bermula pada tahun 1865 apabila 60 orang buruh Cina dari Labuan dan Hong Kong telah tiba di Papar untuk membangunkan koloni Ellena di Sungai Kimanis yang merupakan sebuah kawasan yang berjaya diperoleh oleh American Trading Company of Borneo daripada Kesultanan Brunei (Hill \& Voo, 1990:194-218).

Setelah mendapat piagam diraja daripada kerajaan Britain untuk mentadbir Borneo Utara, SBUB menyedari bahawa kekurangan tenaga buruh merupakan masalah utama wilayah tersebut dan elemen ini penting dalam pembangunan sebuah tanah jajahan baru. Oleh itu, SBUB mengambil langkah dengan membawa masuk orang luar demi perkembangan perekonomian Borneo Utara. SBUB menjadikan orang Cina sebagai pilihan utama kerana menyaksikan bagaimana pembangunan di kolonikoloni British yang lain seperti Hong Kong dan Singapura yang mempunyai ramai orang Cina. SBUB yakin dengan potensi orang Cina sebagai golongan yang bukan sahaja boleh menyumbang kepada hasil kerajaan melalui kerajinan mereka, tetapi juga melalui kutipan duti dan cukai daripada penggunaan candu, perjudian dan meminum arak yang merupakan tabiat normal orang Cina (Wong, 1999:135).

Justeru matlamat untuk menarik kemasukan orang Cina ke Borneo Utara menjadi agenda penting dalam perkiraan dasar ekonomi SBUB selepas itu. SBUB telah memperkenalkan pelbagai skim sepanjang tempoh 1881 sehingga 1941, termasuklah Skim Medhurst (1882-1886), Skim Persatuan Basel Missionari (1905-1914) dan Skim Tambang Percuma (1921-1941) (Wong, 1999). Skim-skim ini telah membawa masuk peneroka dan migran bebas ke Borneo Utara, walaupun terdapat juga migran bebas yang datang sendiri tanpa mengikuti sebarang skim. Ada di antara migran bebas ini yang menjadi buruh setibanya mereka di Borneo Utara. Selain daripada itu, ada juga orang Cina yang telah direkrut khas sebagai buruh untuk bekerja di sektor ekonomi Borneo Utara. Secara umumnya, orang Cina yang berada di Borneo Utara kebanyakannya adalah berketurunan Kantonis, Teochiu, Hokkein dan Hakka. Sejak dekad kedua abad ke-20 kaum Hakka merupakan kaum Cina yang paling ramai di Borneo Utara.

Kehadiran orang Cina di Borneo Utara seperti mana juga kewujudan mereka di tempat-tempat lain di dunia dipengaruhi oleh pelbagai faktor penolak dan penarik yang membawa kepada diaspora orang Cina dari tempat asal mereka. Dari segi faktor penolak misalnya, di negara China, pemberontakan dan revolusi amat meluas berlaku pada abad ke-19 dan 20 akibat ketidakpuasan hati rakyat terhadap penindasan, ketidakcekapan pentadbiran kerajaan dan kemiskinan. Ini termasuklah Pemberontakan Taiping 1857-1864, Pemberontakan Boxer 1900, pergolakan politik di antara Yuan Shih Kai dan Sun Yat Sen menyebabkan kacau bilau dan perang saudara berlaku. Selain daripada faktor keselamatan, 
kepadatan penduduk menyebabkan pengangguran amat tinggi, terutamanya di bahagian selatan China. Di wilayah Guangdong (Kwantung) dan Fujian (Fukien) misalnya, penduduknya amat reseptif kepada idea emigrasi kerana sejarah perdagangan maritim dan petempatan yang telah wujud sejak awal menggunakan laluan sutera maritim melibatkan Asia Tenggara, Asia Selatan, Asia Barat dan Eropah. Akhir sekali, malapetaka semula jadi sering berlaku seperti banjir dan kemarau yang menjejaskan hasil pertanian dan ekosistem makanan sehingga membawa kebuluran (Ee, 1961:33-35). Dalam konteks masyarakat Hakka pula, emigrasi mereka banyak dipengaruhi oleh penindasan dan penganiayaan ke atas mereka kerana dipercayai menjadi penyokong utama kepada pemberontakan Taiping. Mereka yang berada di Guangdong pada lewat 1880an juga adalah Kristian, dan secara relatifnya pro-Eropah. Semasa pemberontakan Boxer pada 1900 yang melibatkan penentangan terhadap kristianiti dan kolonialisme Eropah, orang Hakka berpihak kepada British menyebabkan mereka menjadi sasaran penindasan (Simons, 2019). Keselamatan yang terancam menyebabkan ramai yang mengambil keputusan untuk bermigrasi keluar.

Faktor-faktor banjir, kemarau, kebuluran, pemberontakan, diskriminasi dan pertambahan populasi sememangnya penting dalam menggalakkan emigrasi luar, namun faktor penarik juga memainkan peranan penting dalam menentukan hala tuju dan jumlah migrasi. Dalam erti kata lain, kondisi dalaman dan luaran bergerak selari yakni jika tidak ada pemacu dalaman, emigrasi tidak akan/mungkin berlaku, dan jika tidak ada peluang ekonomi di tempat lain, maka tidak ada destinasi yang akan dituju. Dalam konteks faktor penarik, akhir abad ke-19 dan awal abad ke-20 menyaksikan permintaan tinggi bagi buruh di Borneo Utara (dan pelbagai koloni lain) bagi membolehkan sektor ekonomi skala besar seperti perladangan tembakau dan getah, pembalakan dan perlombongan berkembang. Masalah kekurangan sumber tenaga buruh hanya boleh diatasi dengan menggalakkan imigrasi.

Selain daripada itu, perubahan sikap kerajaan China terhadap emigrasi juga telah menjadi pendorong kepada emigrasi ke destinasi luar. Sekatan terhadap emigrasi semakin longgar pada pertengahan abad ke-19, dan menjelang tahun 1860, kerajaan Imperial China telah menandatangani konvensyen dengan British dan Perancis di mana rakyat Cina dibenarkan bermigrasi dan bekerja di seberang laut (Ee, 1961:36). Pada tahun 1904, satu lagi perjanjian telah ditandatangani di London di antara kerajaan China dan British untuk menyelia bersama migrasi buruh melalui sistem-kredit atau kontrak (indenture) Cina. Perjanjian ini dikenali sebagai Emigration Convention between the United Kingdom and China Respecting the Employment of Chinese Labour in British Colonies and Protectorates (Ritherdon, 1920:577). Justeru itu, pada abad ke-20 mingrasi orang Cina ke seberang laut telah menjadi sah di sisi undang-undang. Tidak lagi perlu gusar mereka akan dikenakan denda jika mereka bermigrasi, maka fenomena migrasi rakyat Cina berterusan.

Orang Cina yang bekerja sebagai buruh di Borneo Utara datang melalui pelbagai saluran. Pada asasnya mereka datang dari negara China melalui pelabuhan Singapura dan akhirnya ke Borneo Utara, atau secara langsung terus dari China ke Borneo Utara. Perjalanan melalui Singapura juga melibatkan dua senario, iaitu migran yang telah tamat kontrak dan direkrut semula di Singapura (laukeh), dan migran baru yang direkrut di China (singkeh) dan dibawa melalui Singapura. Bagi buruh yang direkrut di negara China, kebanyakan daripada mereka ini terlalu miskin dan tidak mampu membayar tambang sendiri. Akibatnya mereka telah direkrut di selatan China sama ada dengan menggunakan sistem kredit-tiket atau sistem buruh kontrak. Di bawah sistem yang pertama, semua perbelanjaan dalam perekrutan di China termasuk penghantaran buruh akan ditanggung oleh broker khas. Apabila tiba di Singapura, mereka akan dicari pekerjaan oleh broker-broker ini. Dalam sistem buruh kontrak pula, kos pengangkutan buruh akan ditanggung terus dari China ke Singapura/Borneo Utara oleh syarikat yang memerlukan khidmat buruh tersebut.

Dalam satu spektrum yang lain, terdapat juga orang Cina yang asalnya adalah migran bebas (juga dikenali sebagai buruh bebas dalam sumber) terlebih dahulu dan setibanya mereka di Borneo Utara, mereka bebas untuk mencari pekerjaan. Ini termasuklah menjadi buruh dan menandatangani kontrak tempatan selama satu tahun, atau kurang. 'Bebas' juga bermaksud migrasi tanpa melalui broker perburuhan di tempat asal mereka. Migran bebas hanya akan menandatangani kontrak kerja setelah tiba di Borneo Utara. Apabila mereka tiba di Borneo Utara, majikan/estet yang mengambil mereka bekerja 
akan membayar tambang mereka dari Hong Kong dan akan memberikan mereka wang pendahuluan (biasanya sebanyak \$30) selepas menandatangani kontrak (BNBH, 1 April 1889).

Kemasukan buruh Cina pertama di Borneo Utara di bawah SBUB ialah pada Oktober 1881 apabila seramai 29 orang buruh Kantonis Macau telah tiba di Sandakan melalui Singapura dengan menggunakan kapal wap S.S Royalist. Ini merupakan laluan pertama yang digunakan untuk membawa buruh Cina ke Borneo Utara semasa era pentadbiran SBUB, yakni menggunakan laluan maritim dari Hong Kong ke Singapura, dan dari Singapura ke Borneo Utara. Kapal-kapal wap milik Blue Funnel Line akan beroperasi dari Hong Kong ke Singapura dan mengangkut buruh-buruh Cina yang direkrut dari selatan China (Middlemiss, 11 Disember 2018). Terdapat sumber yang menyatakan bahawa residen pertama Sandakan, William B. Pryer telah menghantar orang gajinya dari etnik Cina ke Singapura untuk mendapatkan khidmat buruh-buruh Kantonis ini (Wong, 1999:135).

Senario penghantaran agen ke Singapura untuk memperoleh buruh Cina seperti mana yang telah dilakukan oleh Pryer ini amat konsisten dengan rangkaian perburuhan yang wujud di Singapura dan Pulau Pinang pada masa itu di mana agen kerajaan atau majikan akan menunggu ketibaan buruh Cina dan membawa mereka balik ke Borneo Utara. Walau bagaimanapun, rangkaian perekrutan ini mempunyai imej yang buruk kerana ia pernah dikaitkan dengan isu penindasan atau penganiayaan. Sebenarnya, sistem kredit-tiket dan buruh kontrak Cina memerlukan rangkaian broker dan agen perekrutan yang besar. Broker-broker di Cina dan Singapura mempunyai hubungan erat dengan pemilik-pemilik rumah sewa di Swatow, Amoy, termasuk juga di Hong Kong dan Macau, yakni kawasan-kawasan datangnya kebanyakan migran atau buruh dari China. Buruh yang direkrut akan ditempatkan di rumah-rumah yang disediakan khas ini dan mereka akan diangkut terus menggunakan kapal laut ke destinasi. Pemilik-pemilik kapal ini biasanya akan mengangkut jumlah buruh seramai mungkin, dan kapal amat sesak, tanpa mengambil kira soal keselesaan, kebersihan dan muatan. Terdapat tohmahan bahawa buruh-buruh Cina ini diperlakukan seperti binatang (Blyth, 1947). Apabila kapal-kapal yang mengangkut buruh ini sampai di koloni, agen-agen kepada majikan akan berkerumun di kapal untuk sesi tawar-menawar dengan broker buruh Singapura. Buruh yang tidak diminati akan kekal di atas kapal atau ditempatkan di barak sekitar pelabuhan dan menunggu sehingga ada majikan menerimanya. Barak ini biasanya selalu didokong oleh kumpulan kongsi gelap Cina. Walaupun perundangan telah diwujudkan pada lewat abad ke-19 dan awal abad ke-20 untuk mengawal selia sistem perekrutan buruh Cina dan keadaan semakin pulih, rangkaian perekrutan ini masih diselubungi elemen pengeksploitasian dan penganiayaan (Blyth, 1947).

Untuk menggalakkan kemasukan buruh dan peneroka Cina ke Borneo Utara, langkah pertama diambil oleh kerajaan SBUB ialah melantik Sir Walter Medhurst sebagai Pesuruhjaya Imigresen pertama. Setibanya di China pada tahun 1882, Medhurst mewar-warkan peluang bermigrasi ke Borneo Utara dengan tambang percuma dan berjaya menarik sebilangan penduduk tempatan untuk berpindah. Melalui pengaturan khas yang dilakukan oleh Medhurst, buruh Cina telah direkrut tanpa campur tangan broker-broker tempatan seperti yang berlaku di Pulau Pinang dan Singapura (BNBH, 1 Oktober 1883). Secara keseluruhannya, terdapat lima penghantaran imigran Cina ke Borneo Utara di bawah skim Medhurst. Penghantaran yang pertama hanya melibatkan 43 orang sementara penghantaran yang kedua berlaku pada bulan Oktober 1882 dengan 225 orang migran. Bagi kedua-dua penghantaran ini, mereka menggunakan kapal wap S.S. Hainan dengan pergerakan kapal dari Hong Kong ke Borneo Utara melalui Singapura (Wong, 1999:137).

Selepas itu, Medhurst telah mengambil inisiatif untuk mewujudkan jaringan pengangkutan secara langsung di antara Borneo Utara dengan China tanpa perlu singgah di Singapura terlebih dahulu. Berbekalkan modal yang telah diberikan oleh SBUB, sebuah kapal wap telah disewa khas bagi tujuan ini, iaitu S.S. Fokien, kapal milik British (814 tan) yang dibina oleh Hall, Russell \& Co. Ltd. di Aberdeen, Scotland, pada tahun 1880. Kapal S.S. Fokien yang beroperasi di pelabuhan Hong Kong, Swatow dan Amoy merupakan kapal wap pertama yang mengibarkan bendera SBUB dan bergerak dari Hong Kong ke pelabuhan Borneo Utara (BNBH, 1 Mac 1883:7). S.S. Fokien membawa penumpang dan berlabuh di pelabuhan Kudat sebelum meneruskan perjalanan ke Singapura. Emigrasi skim Medhurst ketiga dan keempat masing-masing berlaku pada Januari 1883 (340 imigran Cina) dan April 1883 dengan menggunakan kapal S.S. Fokien. Emigrasi yang kelima melibatkan 114 penumpang Cina 
dengan menaiki kapal S.S. Thales dari Hong Kong. Jadual keluar masuk kapal-kapal wap ini telah dilaporkan dalam akhbar tempatan British North Borneo Herald. Secara keseluruhannya, jumlah migran Cina yang tiba di Borneo Utara di bawah skim Medhurst adalah lebih kurang 1000 orang yang terdiri daripada pelbagai kategori - peniaga kecil-kecilan, buruh, tukang jahit, petani - dengan kualiti dipertikaikan (Wong, 1999:137).

Perkembangan Borneo Utara dari segi pentadbiran dan ekonomi telah mempertingkatkan keterlihatan wilayah jajahan SBUB ini, lantas menjadi pemangkin kepada pertambahan kapal-kapal wap baru dari Hong Kong di pelabuhan-pelabuhan Borneo Utara, terutamanya Kudat dan Sandakan. Antara majikan/syarikat perniagaan yang beroperasi di Borneo Utara yang mendapat khidmat daripada kapalkapal wap ini bagi tujuan mengangkut buruh Cina dari Hong Kong adalah seperti British Borneo Timber Company, Borneo Tabak Maatschappij, London Borneo Company, Rotterdam Borneo Maatschappij, China Borneo Company, Lahad Datu Estates dan banyak lagi. Akhbar Herald seringkali melaporkan tentang ketibaan golongan buruh ini dengan maklumat-maklumat seperti nama kapal wap yang mengangkut mereka, pelabuhan asal, jumlah dan kategori migran Cina yang datang, serta nama majikan di Borneo Utara. BNBH bertarikh 23 Jun 1890 misalnya, telah melaporkan tentang The East Borneo Planting Company menyewa kapal wap Loong Mon milik Messrs. Butterfield and Swire Co. pada 25 Mei 1889 untuk membawa masuk 150 orang buruh Cina untuk bekerja di estet tembakau dan kopi di Sandakan dan Teluk Darvel (BNBH, 23 Jun 1890). Kapal wap Changsa milik China Navigation Company telah membawa 300 buruh untuk bekerja di estet tembakau di Sg. Kinabatangan yang dimiliki oleh China Borneo Land \& Farming Company (BNBH, 12 Januari 1892). Akhbar juga melaporkan tentang ketibaan kapal dengan buruh Cina atas inisiatif majikan sendiri: -

"Count Geloes arrived at Kudat on the $31^{\text {st }}$ March in the s.s. Afghan from Hongkong, four days out, bringing 156 Chinese Coolies for the Ranow Estate belonging to the Borneo Tabak Maatschappy of which Company the Count is Managing Director." (BNBH, 1 Mei 1888:393).

Kapal-kapal wap tambahan yang pernah beroperasi dari perairan Hong Kong ke Borneo Utara sebagai kapal pengangkut penumpang yang turut membawa buruh kontrak atau buruh bebas Cina adalah S.S. Amatista, S.S. Memnon, S.S. Afghan, S.S. Tayuan, S.S. Ascanius, dan S.S. Normanby (BNBH, 1 Jun 1888; BNBH, 1 April 1889). Kapal-kapal ini kebanyakannya berjadual dan akan singgah dalam perjalanan ke Singapura untuk memunggah kargo atau menurunkan buruh, peneroka dan migran bebas di pelabuhan Borneo Utara.

Perjalanan langsung dari Hong Kong ke Borneo Utara biasanya hanya mengambil masa 4 hari setengah sahaja, dan perjalanan yang secara relatifnya lebih pendek ini dipercayai boleh/telah menjadi daya tarikan buruh ke Borneo Utara pada masa tersebut berbanding dengan destinasi lain yang lebih jauh seperti Tanah Melayu atau Deli, Sumatera, yang turut mengimport buruh Cina. Pada masa yang masa, dengan bantuan agen di Hong Kong dan kedudukan geografi Borneo Utara yang berhampiran, pemilik-pemilik estet di Borneo Utara dapat mengurangkan kos pengimportan buruh di mana mereka boleh memperoleh empat orang buruh sekali gus bagi harga seorang buruh yang biasa ditanggung oleh pesaing mereka di Deli (BNBH, 1 Mei 1888). Majikan di estet Teluk Marudu pernah menyatakan bahawa mereka amat berpuas hati dengan buruh yang mereka terima secara langsung dari Hong Kong dengan bantuan Messrs Birley Dalrymple \& Co. di Hong Kong kerana mereka hanya membayar satu pertiga daripada harga asal yang biasa mereka bayar menerusi agen Singapura mereka, Agency of Singapore Towkays, jika buruh Cina diimport melalui Singapura (BNBH, 1 Jun 1888).

Selain daripada isu kos, pengimportan buruh Cina menggunakan laluan terus dari Hong Kong ke Borneo Utara juga menjadi pilihan majikan kerana ramai yang terpaksa menganggung kerugian apabila buruh mereka melarikan diri apabila menggunakan laluan Singapura. Pada asasnya, majikan telah memberi wang pendahuluan kepada buruh-buruh ini apabila buruh bersetuju untuk bekerja di Borneo Utara. Walau bagaimanapun, ramai buruh Cina telah melarikan diri setibanya mereka di pulau Labuan, yakni pelabuhan pertama yang disinggahi oleh kapal wap dari Singapura sebelum sampai di tanah besar Borneo Utara. Fenomena ini agak berleluasa berlaku di Labuan kerana tindakan melanggar kontrak bukanlah suatu kesalahan jenayah di pulau Labuan, tidak seperti di Singapura, menyebabkan 
ramai yang tidak mahu mengambil risiko melarikan diri di Singapura. Ekoran daripada itu, buruh yang berjaya melarikan diri akan naik semula kapal wap yang singgah di pelabuhan Labuan dan kembali ke Singapura. Hanya apabila SBUB mengambil alih pentadbiran Labuan pada tahun 1890 barulah isu ini berjaya ditangani (Tregonning, 2007:166).

Keghairahan untuk memperoleh buruh bebas atau buruh kontrak Cina adalah sejajar dengan kemuncaknya perkembangan tembakau pada tahun 1890 bila mana kerajaan mengambil inisiatif untuk merangsang migrasi orang Cina pada masa ini. Sebelum itu, yakni pada awal tahun 1889 Messrs. Bradley \& Co. telah dilantik sebagai agen kepada SBUB di Swatow untuk menggalakkan migrasi buruh bebas (dan buruh kontrak) ke Borneo Utara. Tidak lama selepas itu, bermula pada bulan Februari 1889, akhbar BNBH melaporkan tentang ketibaan buruh bebas yang menaiki kapal S.S. Memnon untuk mencuba nasib mereka di perladangan tembakau di estet Kudat dan Teluk Marudu (BNBH, Februari 1889). Sehingga tahun 1891 ketibaan migran/buruh bebas dari Hong Kong masih dilaporkan sekali sekala oleh akhbar, misalnya S.S. Memnon dan S.S. Normanby. Golongan buruh bebas yang mereka perolehi adalah dari sektor 'Hailo-Hong' (BNBH, 1 April 1891), sempena nama bandar-bandar berhampiran Swatow iaitu Hai Hong dan Lo Hong, di mana mereka mempunyai klan di wilayah Kwangtung (Fernando \& Bulbek, 1992:204). Majikan di Borneo Utara teruja dengan buruh bebas yang diperolehi dari kawasan Hailo-Hong yang diibaratkan sebagai "... the best coolies procurable from China" (BNBH, 1 April 1891). Estet di Teluk Marudu mengalu-alukan kehadiran mereka, begitu juga beberapa estet di pantai timur. Di estet Lahad Datu di Teluk Darvel, sumber merekodkan 60 orang buruh bebas diambil bekerja sebagai buruh dengan kontrak bertulis dan dibayar gaji yang agak tinggi, berbanding dengan kadar biasa. Buruh bebas di Sandakan juga ada yang dibayar sehingga 60 sen sehari, dan untuk kerja-kerja khas bagi jangka masa pendek, buruh boleh diupah sehingga \$1 sehari (BNBH, 1 Januari 1891).

Terdapat juga perkhabaran tentang kapal S.S. Memnon akan singgah di pelabuhan Hoihow (kini dikenali sebagai Haikow) di utara pulau Hainan untuk mengangkut migran bebas (BNBH, 1 Mac 1891) namun perkara ini tidak dapat disahkan sama ada berlaku atau tidak pada masa tersebut kerana tidak dinyatakan dalam sumber. Majikan sememangnya menyasarkan Pulau Hainan sebagai sumber migran bebas kerana kawasan ini miskin dan kurang pembangunan (Nield, 2012:64). Selain itu, pelbagai desas-desus berkaitan dengan penjarahan ke atas buruh/migran di rumah-rumah broker di Hong Kong dan ke atas kapal-kapal di pelabuhan Hong Kong sampai ke telinga majikan, dan jika migran bebas atau buruh boleh diangkut dari Hoihow secara terus maka para majikan percaya kejadian yang negatif seperti yang dinyatakan boleh dielakkan (BNBH, 1 Mac 1891). Walau bagaimanapun, pelabuhan Hoihow yang cetek menyebabkan kesukaran bagi kapal untuk masuk singgah ke pelabuhan ini (Rhoads, 1975:16).

Kemasukan buruh Cina ke Borneo Utara selepas tahun 1890 berkurangan disebabkan oleh pelbagai faktor yang saling berkaitan. Pertama, adalah skandal bersabit jumlah kematian buruh Cina yang ramai di estet perladangan Borneo Utara yang dipercayai telah memburukkan imej Borneo Utara sebagai destinasi buruh/migran Cina. Kedua, Pengarah SBUB Cowie tidak mahu membiayai sebarang pelan migrasi dari China dan mahu bergantung sepenuhnya kepada penduduk peribumi dari kawasan pedalaman. Ketiga, Governor Beaufort telah memperkenalkan cukai ke atas beras pada tahun 1895 di mana kenaikan sebanyak 5\% ke atas makanan ruji (beras) orang Cina bukan sahaja telah menghentikan imigrasi orang Cina tetapi ia juga telah membawa kepada emigrasi keluar mereka dari Borneo Utara (Tregonning, 2007:170). Apabila cukai beras dimansuhkan pada tahun 1903, imigran Cina secara perlahan-lahan kembali namun kebanyakan mereka terdiri daripada orang Hakka dan Kantonis yang mendapat tanah atau bekerja di kawasan pembinaan landasan keretapi. Dari tahun 1912 hingga 1914, skim kemasukan orang Cina adalah di bawah Basel Mission Society, Lutherans yang telah membawa masuk orang Hakka yang ditempatkan di kawasan petempatan di Kudat, Inanam dan Telipok (Wong, 1999).

Semasa Perang Dunia Pertama, tiada apa-apa yang telah dilakukan untuk merangsang aliran masuk imigran Cina ke Borneo Utara baik sebagai buruh mahupun migran bebas dan peneroka. Pada tahun 1920 barulah skim imigrasi yang baru yang dikenali sebagai Skim Tambang Percuma atau Skim Pas Percuma diperkenalkan melibatkan kerjasama peneroka Cina di Borneo Utara, di mana mereka yang 
mempunyai tanah kurang daripada 25 ekar boleh memperoleh pas percuma dari Pejabat Daerah untuk dihantar kepada keluarga mereka di China, lantas melayakkan keluarga mereka untuk mendapatkan pas percuma dari agen SBUB di Hong Kong untuk datang ke Borneo Utara. Skim ini bermatlamat untuk menarik peneroka dan bukan buruh. Pada waktu ini sektor ekonomi skala besar yang memfokuskan kepada tanaman getah lebih banyak bergantung kepada penggunaan buruh Jawa.

\section{Isu Perkapalan dan Pengangkutan buruh Jawa}

Selain daripada buruh Cina, buruh Jawa merupakan buruh kedua teramai yang dibawa masuk oleh pihak SBUB ke Borneo Utara. Kemasukan buruh Jawa ke Borneo Utara bermula apabila pentadbiran di Pulau Jawa diambil alih oleh pihak kolonial Belanda selepas kemuflisan Syarikat Hindia Timur Belanda (Veregnide Oostindische Compaigne, VOC). Pada abad ke-19 dan awal abad ke-20, migrasi keluar masyarakat Jawa telah berlaku akibat daripada pelbagai faktor dalaman dan luaran menyebabkan ramai yang direkrut sebagai buruh kontrak di pelbagai destinasi di dunia, termasuklah Borneo Utara.

Secara umumnya, sepanjang era pentadbiran SBUB dari 1881 hingga 1941 perekrutan buruh Jawa bagi Borneo Utara dilakukan mengikut dua saluran iaitu saluran swasta dan saluran rasmi yang melibatkan permit khas dari kerajaan kolonial Belanda. Kewujudan buruh Jawa di Borneo Utara telah dikesan seawal 1882 melalui saluran tidak rasmi apabila seramai 70 orang Jawa telah direkrut di Singapura oleh agen SBUB untuk dihantar ke stesen pertanian di Silam. Estet perladangan milik Belanda di Borneo Utara juga sekali sekala akan meminta broker buruh swasta di Singapura untuk membekalkan buruh Jawa kepada mereka sekiranya diperlukan (Tregonning, 2007:176). Di antara tahun 1907-1909 pula, seramai 8449 buruh Jawa telah direkrut di Pulau Jawa atas permit rasmi kerajaan yang pertama, namun hampir 60\% daripada mereka telah kembali ke Pulau Jawa selepas penamatan kontrak mereka (Tregonning, 2007:176).

Bermula dari dekad kedua abad ke-20, migrasi buruh Jawa ke Borneo Utara semakin rancak. Kerajaan SBUB mendapat permit untuk merekrut buruh Jawa secara langsung di Pulau Jawa bermula pada tahun 1914 dan permit ini sering kali diperbaharui sehinggalah ia tamat pada tahun 1932. Kontrak akan ditandatangani di Pulau Jawa selama dua tahun (tiga tahun bermula pada tahun 1929). Sejajar dengan itu juga, fasa ini turut memperlihatkan perekrutan aktif buruh Jawa oleh syarikat atau broker buruh atas biayaan para majikan di Borneo Utara (De Silva, 2009). Saluran swasta akan merekrut buruh Jawa di Singapura dan kontrak selama setahun (boleh diperbaharui) hanya boleh ditandatangani setelah mereka tiba di Borneo Utara sendiri. Untuk membezakan di antara kedua-dua golongan buruh ini, kontrak di bawah permit kerajaan dikenali sebagai Kontrak Jawa (Dutch Contract) sementara buruh Jawa rekrutan swasta pula menandatangani kontrak bertulis yang dikenali sebagai Kontrak Lokal (Local Contract). Secara keseluruhannya, dari tahun 1914-1932, lebih kurang 19,376 buruh Jawa telah direkrut atas kedua-dua kontrak untuk bekerja di Borneo Utara (De Silva, 2011).

Buruh Jawa yang diperolehi untuk Borneo Utara direkrut di bandar-bandar utama seperti Betawi, Semarang dan Surabaya. Namun kebanyakan mereka berasal dari kawasan Karang Tembok, Kapasan, Kebumen, Pati, Yogyakarta dan Blitar (CO874/744). Walaupun sangat bergantung kepada buruh yang direkrut dari Jawa Tengah dan Jawa Timur, terdapat juga buruh yang diperoleh dari kawasan yang menggunakan bahasa Sunda seperti Bandung dan Betawi, dan bahasa Madura. Secara keseluruhannya kecenderungan orang Jawa untuk bermigrasi dan direkrut sebagai buruh kontrak pada lewat abad ke19 dan pertengahan pertama abad ke-20 banyak bergantung kepada masalah ledakan populasi, kekurangan makanan, kemiskinan dan kekurangan tanah untuk pertanian (Lockard, 1977; Geertz, 1956). Terdapat juga mereka yang melarikan diri kerana afliasi politik dan kebimbangan akan dihukum kerana aktiviti jenayah (De Silva, 2019); Hugo, 1982; Wong, 2004). Menjelang 1930, lebih kurang 1,200,000 atau $2.9 \%$ orang Jawa yang bermigrasi ke luar pulau Jawa (Lockard, 1977). Ramai daripada mereka direkrut sebagai buruh di Pulau Jawa untuk bekerja di koloni Belanda atau British seperti di Sumatera, Surinam, Tanah Melayu, Borneo Utara, Sarawak, New Caledonia antara lainnya.

Buruh Jawa akan direkrut oleh agen perekrutan berlesen seperti Messr. Soesman and Co. bagi mereka yang direkrut atas permit kerajaan (Kontrak Belanda) dan oleh Labour Association yang berpusat di 
Singapura bagi perekrutan swasta. Semua buruh yang direkrut di Pulau Jawa bagi Borneo Utara haruslah melalui pelabuhan Singapura terlebih dahulu dan perlu melalui pemeriksaan oleh Konsul Belanda di Singapura (CO874/744, Surat Sonneveld kepada Clark, 8 April 1913). Selain daripada itu, buruh Jawa juga direkrut di Singapura sendiri terutamanya mereka yang telah menghabiskan kontrak asal. Perekrutan dilakukan oleh Labour Association atau orang tengah seperti 'sheikh buruh' bagi pihak majikan (De Silva, Julai 2011).

Kerajaan SBUB telah mengajukan idea kepada beberapa syarikat perkapalan antarabangsa milik Belanda dan Jerman agar memperkenalkan laluan langsung dari Pulau Jawa ke Borneo Utara berdasarkan kepada keberadaan mereka di kawasan perairan tersebut. Syarikat perkapalan Java-China Japan Line milik Belanda misalnya memulakan operasi mengangkat penumpang sejak tahun 1902 (dan menjelang tahun 1931, memiliki 13 kapal yang beroperasi di perairan Asia Timur), dan akan berhenti di beberapa pelabuhan persinggahan termasuk di Kalimantan Borneo (Stanford, c1930). Begitu juga dengan kapal milik Jerman, Norddeutscher Lloyd (NDL), yang sudah ada jadual pelayaran hingga ke Bolongan di utara Kalimantan, dan hanya perlu memperluaskan sedikit perjalanannya sehingga ke Tawau, yakni sebuah daerah di pantai timur Borneo. Walau bagaimanapun, idea ini tidak berhasil kerana tiga faktor utama iaitu kadar bayaran yang terlalu tinggi, syarikat perkapalan tidak mempunyai kapal tambahan untuk digunakan, dan jika adapun kerajaan Belanda tidak berkenan dengan kapal/syarikat perkapalan yang dicadangkan, lantas menggagalkan inisiatif tersebut (De Silva, 2009:85).

SBUB tiada pilihan lain dan buruh-buruh Jawa telah diangkut ke Borneo Utara dari pelabuhan Semarang menggunakan kapal Straits Steamship Company, dan melalui pelabuhan Singapura. Syarikat Straits Steamship Company yang diasaskan di Singapura telah berjaya menembusi perdagangan segitiga di antara Asia Tenggara, China dan India dengan menyediakan kapal-kapal yang lebih pantas dan efisyen untuk digunakan di laluan maritim yang menghubungkan kawasan-kawasan ini. Menjelang tahun 1914, SSC memiliki 17 buah kapal yang beroperasi dalam jaringan perdagangan maritim yang ekstensif, termasuk di perairan Pulau Jawa, Sumatera, dan kepulauan Borneo (Tregonning, 1967). SSC menjadi semakin dominan apabila semua kapal wap Norddeutscher Lloyd milik Jerman telah dihentikan penggunaan selepas Perang Dunia Pertama, dan Alfred Holt \& Co., berasaskan perjanjian dengan SSC, telah membekalkan kapal-kapal baru kepada SSC untuk memperluaskan operasinya (Huff, 1994:146). Selepas 1914 juga hanya Koninklijke Paketvaart Mij. (KPM) sahaja syarikat perkapalan Eropah yang menjadi saingan kepada SSC yang beroperasi di Singapura. Namun, dalam tempoh antara Perang Dunia Pertama dan Perang Dunia Kedua, KPM terpaksa meletakkan beberapa kapalnya di Singapura dan menganggap pelabuhan Singapura sebagai "head port" kerana sebahagian besar perdagangannya dengan Sumatra dan Borneo berpusat di Singapura. Walau bagaimanapun, KPM mengehadkan perluasan penggunaan kapalnya di Singapura disebabkan ingin mempromosikan kepentingan komersil Belanda dan juga kerana wujudnya perjanjian dengan SSC. Perjanjian yang dimaksudkan ini merujuk kepada wujudnya kartel berpunca daripada keunggulan SSC dan KPM dan keterlibatan mereka dalam persidangan maritim yang telah membawa kepada keinginan untuk menyekat persaingan di perairan wilayah. Sebagai sebahagian daripada rundingan yang juga melibatkan Holts dan anggota Java Homeward Conference yang merupakan pemegang saham besar dalam KPM, syarikat perkapalan SSC dan KPM pada tahun 1924 telah mencapai kesepakatan komprehensif yang membahagikan laluan perkapalan tempatan dan menetapkan kadar pengangkutan (Huff, 1994:148).

Syarikat SSC akan menghantar buruh Jawa dari pelabuhan Semarang di Jawa Tengah. Broker perburuhan yang dilantik oleh SBUB, Messrs. Soesmann \& Co. akan mengumpul buruh-buruh yang telah direkrut dari seluruh Jawa dan ditempatkan di depoh pelabuhan sementara menunggu keberadaan kapal SSC untuk mengangkut mereka ke Singapura. Seminggu sebelum kapal wap bertolak, agen di Singapura iaitu syarikat Labour Association akan dimaklumkan terlebih dahulu berkenaan jumlah buruh yang akan dihantar agar persediaan dapat dilakukan (CO874/753, Hall kepada Setiausaha Kerajaan, 19 Oktober 1920). Persediaan yang dimaksudkan ini termasuklah penyediaan tempat tinggal di depoh buruh di Kallang. Berapa lama buruh Jawa akan tinggal di depoh ini bergantung kepada pemeriksaan Konsul-Jeneral Belanda di Singapura, dan juga jadual waktu pergerakan kapal wap ke ke Borneo Utara. Jika jadual waktu perjalanan kapal ke Borneo Utara adalah tidak menentu, buruh Jawa 
akan dikuarantin terlebih dahulu di Pulau St John's (kini dikenali sebagai Pulau Sekijang Bendera), yakni kira-kira 6.5km dari bandar utama Singapura (CO648/8, Annual Report Protectorate Dept 1918). Pada waktu itu, Pulau St. John's merupakan salah satu daripada stesen kuarantin terbesar selepas Pulau Ellis di New York, dan berfungsi sebagai pusat kuarantin golongan imigran untuk memastikan mereka bebas dari sebarang penyakit (Huff, 1994:46-47). Di pusat kuarantin ini buruh-buruh juga akan 'dikawal' dengan rapi untuk mengelakkan mereka 'terlepas'.

Isu perkapalan merupakan isu utama yang dihadapi oleh kerajaan SBUB bersabit dengan penghantaran buruh Jawa. Perkhidmatan perkapalan SSC yang amat terhad dari Semarang ke Singapura telah menjejaskan jumlah buruh yang dihantar. Kelewatan penghantaran akibat ketiadaan atau kelambatan kapal telah mendorong buruh untuk berubah fikiran atau melarikan diri (CO874/744, Laporan M.M. Clark). Inisiatif untuk mewujudkan perkhidmatan penghantaran buruh dari pelabuhan Betawi ke Singapura sebagai tambahan kepada perkhidmatan sedia ada (dari Semarang ke Singapura) telah dilakukan oleh J. Maxwell Hall, wakil kerajaan SBUB, dalam lawatannya ke Jawa pada tahun 1920. Menurut Maxwell, adalah lebih baik jika semua buruh yang direkrut untuk Borneo Utara yang menunggu di depoh Betawi dihantar dengan segera. Ini perlu kerana buruh yang menunggu di depoh Betawi akan hilang kesabaran akibat kelewatan kapal dari Semarang. Persaingan daripada pihak lain, terutamanya buruh Jawa ke destinasi Deli di Sumatera, juga tidak membantu Borneo Utara dalam aspek ini kerana kapal-kapal milik Koninklijke Paketvaart Maatschappij (KPM) sentiasa ada untuk mengangkut buruh sama ada dalam kuantiti besar atau kecil. Majikan di Deli juga sanggup menawarkan harga yang tinggi kepada KPM untuk mengangkut buruh dengan segera, suatu yang belum bersedia dilakukan oleh kerajaan SBUB kerana kos sedia ada bagi tujuan pengimportan buruh Jawa amat tinggi (CO874/753, Maxwell kepada Setiausaha Kerajaan, 19 Oktober 1920).

Kos pengimportan yang tinggi ini sentiasa menjadi isu hangat yang diketengahkan oleh para majikan di Borneo Utara. Bagi mereka penyelesaian kepada isu kos ini adalah penghantaran terus buruh dari Pulau Jawa ke Borneo Utara tanpa perlu melalui pelabuhan Singapura. Perkara ini diusul oleh wakil kerajaan SBUB, C.D. Martyn, selaku Protector of Labour, pada tahun 1924 dengan alasan buruh yang tiba dari Singapura mempunyai isu kesihatan dan ramai yang menghidap penyakit kelamin yang dijangkiti di atas kapal dari Singapura (NBCA 1119; De Silva, 2012). Sekali lagi, isu penghantaran terus gagal kerana pihak Borneo Utara tidak mampu memenuhi syarat minimum jumlah buruh yang perlu diangkut sekali masa (150 orang buruh minimum) oleh KPM jika syarikat perkapalan ini memperluaskan operasinya sehingga ke Borneo Utara (CO648/10, Annual Report Protectorat Department, 1924).

Walau bagaimanapun, empat tahun kemudian, semasa rundingan pembaharuan permit pada tahun 1928, kerajaan Belanda akhirnya meluluskan penghantaran langsung buruh Jawa ke Borneo Utara namun harus menggunakan kapal Belanda dan mengibarkan bendera Belanda (CO874/752, Gabenor kepada Presiden SBUB, 10 Jun 1929). Laluan maritim yang digunakan tidak lagi melalui Singapura tetapi adalah di sebelah timur merentasi Laut Jawa, melalui Selat Makasar, dan terus masuk ke perairan Laut Sulawesi, dengan tempat persinggahan di pelabuhan-pelabuhan tanah jajahan Belanda di kota-kota pelabuhan pesisiran pantai Kalimantan sehinggalah kapal sampai ke Tawau di Borneo Utara. Kapal-kapal wap milik KPM digunakan untuk sektor ini dan perjalanan bertambah dari sebulan sekali menjadi dua minggu sekali bermula pada Jun 1929. Kapal wap KPM Rooseboom melakar sejarah dengan menjadi kapal wap pertama yang mengangkut 154 buruh Jawa dan keluarga menggunakan laluan baru ini (BNBH, 16 Oktober 1929). Menjelang akhir tahun 1929, syarakat perkapalan KPM mengangkut seramai 266 buruh Jawa di bawah permit sampai di Tawau dalam empat penghantaran. Selepas itu, era kemelesetan ekonomi dunia yang berlaku bermula pada tahun tersebut hanya memperlihatkan satu kali penghantaran sahaja apabila banyak syarikat/majikan yang terpaksa menghentikan operasi kerana jatuh muflis (CO874/752, Macaskie kepada Setiausaha Kerajaan, 27 April 1928).

Sebenarnya, perubahan sikap Belanda membenarkan penghantaran terus ini dipengaruhi oleh dua faktor utama. Pertama, kerajaan Belanda tidak suka dengan fenomena "kehilangan" buruh Jawa yang dihantar pulang dari Borneo Utara dan mendakwa pelabuhan Singapura menyediakan terlalu banyak peluang untuk perekrutan haram. Jika buruh Jawa yang dihantar balik direkrut semula secara haram 
oleh broker-broker buruh yang berkeliaran di Singapura, sistem perburuhan ini sudah bersifat persendirian dan bukan lagi melalui permit kerajaan. Justeru, buruh Jawa yang direkrut ini tidak akan mendapat keistimewaan hak seperti mana yang dijamin dalam Kontrak Belanda (Kantoor van Arbeid, 1928:38). Faktor kedua merujuk kepada faktor pemonopolian dan dasar perlindungan dengan hanya membenarkan kapal KPM untuk mengangkut semua buruh Jawa ke Borneo Utara. Ini dipengaruhi oleh hubungan istimewa yang wujud di antara kerajaan Belanda dan syarikat perkapalan KPM dengan menekankan monopoli dua hala di mana KPM akan memperoleh monopoli dalam perniagaan melibatkan perkapalan dan laluan maritim pada waktu tersebut dan masa hadapan, dan kerajaan pula mempunyai kawalan ketat terhadap operasi KPM. Ini bermaksud KPM perlu memberi keutamaan untuk mengangkut kargo atau penumpang yang melibatkan urusan kerajaan (termasuk mengangkut buruh Jawa ke Borneo Utara) di samping menjalankan operasi peribadinya (Campo, 2003). Disebabkan oleh dasar perlindungan ini, maka kerajaan Betawi mendakwa kapal yang mengangkut penumpang sebelum ini, yakni kapal SSC, adalah inferior jika dibandingkan dengan kapal KPM. Isu ruang dan bekalan dikatakan tidak mencukupi di atas kapal SSC dan ini termasuklah kekurangan keperluan asas seperti makanan dan air untuk mandi dan minum (Kantoor van Arbeid, 1929:36-37).

\section{Kesimpulan}

Perkembangan teknologi maritim telah memberi impak kepada perkembangan aktiviti perkapalan dan perdagangan, serta membuka lebih banyak laluan maritim yang menghubungkan benua. Semasa era imperialisme baru pada pertengahan kedua abad ke-19, aktiviti maritim memuncak dengan pembukaan kota pelabuhan di koloni, kewujudan syarikat perkapalan dan pengangkutan hasil-hasil tanaman komersil dan eksport lain dari koloni ke destinasi luar. Dalam konteks Borneo Utara, perkembangan ekonomi skala besar telah disokong dengan aktiviti perkapalan yang menghubungkan Borneo Utara dengan beberapa kawasan seperti Singapura, Hong Kong, kepulauan Hindia Timur, Australia dan Amerika Syarikat. Jaringan aktiviti maritim yang luas ini juga telah membantu menyelesaikan masalah kekurangan tenaga buruh di Borneo Utara apabila kerajaan SBUB telah memperoleh sumber tenaga buruh Cina dan buruh Jawa untuk mengusahakan sektor ekonomi skala besar, terutamanya di estet perladangan dan sektor pembalakan. Ternyata usaha membawa buruh Cina dan Jawa masuk ke Borneo Utara banyak bergantung kepada kewujudan kapal-kapal wap milik Jerman, Britain dan Belanda yang beroperasi di perairan Asia yang telah memainkan peranan untuk membawa buruh-buruh ini masuk, yakni buruh Cina dari pelabuhan Hong Kong, sementara buruh Jawa dari Pulau Jawa. Adalah didapati bahawa mereka yang bekerja sebagai buruh di Borneo Utara ini telah masuk sebagai buruh kontrak yakni dengan menandatangani kontrak lebih awal di tempat mereka, atau mereka masuk sebagai migran atau buruh bebas dan menandatangani kontrak pekerjaan setelah tiba di Borneo Utara.

Secara keseluruhannya, dalam mengangkut buruh-buruh ini, isu kos sering dititikberatkan oleh majikan di mana semakin jauh perjalanan, semakin tinggi kos yang akan ditanggung, apalagi jika kos tersebut melibatkan penginapan buruh di pelabuhan persinggahan sementara menunggu jadual kapal beroperasi ke Borneo Utara. Majikan lebih berkenan dengan penghantaran buruh secara terus dari pelabuhan Hong Kong atau Semarang di Jawa, ke Borneo Utara, tanpa melalui pelabuhan Singapura. Perjalanan melalui pelabuhan Singapura melibatkan tambahan kos di samping mempunyai banyak masalah lain. Kecenderungan buruh Cina dan Jawa "hilang" di Singapura tinggi kerana tarikan Singapura, di samping tempoh transit yang panjang kerana ketiadaan kapal wap segera ke Borneo Utara. Ini tentu saja menjejaskan jumlah rekrutmen buruh yang tiba di Borneo Utara. Situasi ini belum mengambil kira perjalanan yang lebih jauh, dengan keadaan kapal yang bersesak, yang turut boleh menjejaskan kesihatan dan kesejahteraan buruh. Akhir sekali, persaingan di antara syarikat perkapalan dan dasar perlindungan yang diamalkan juga merupakan antara faktor dominan yang mempengaruhi dan mencatur agenda perburuhan dan perekonomian Borneo Utara. 


\section{Rujukan}

Becker, B. (2010). Coastal Shipping in East Asia in the Late Nineteenth Century. Journal of the Royal Asiatic Society Hong Kong Branch, 50, 245-302. Diakses pada 13 Julai 2021 dari http://www.jstor.org/stable/23891206.

Blythe, W. (1947). Historical Sketch of Chinese Labour in Malaya. Journal of the Malayan Branch of the Royal Asiatic Society, $20(1$ (141)), 64-114. Diakses pada 10 Julai 2021, dari http://www.jstor.org/stable/41560006.

British North Borneo Herald (BNBH) - 1883-1929.

Campo, J.N.F.M. à (2003). Engines of Empire: Steamshipping and State Formation in Colonial Indonesia. Uitgeverij Verloren.

Colonial Office (CO) 874/744 Javanese Immigration, 1912-1917.

Colonial Office (CO) 874/752 Javanese Immigration, 1924-1930

Colonial Office (CO) 874/753 Javanese Immigration, 1918-1924

Colonial Office (CO) 648/8 Administration Reports, 1917-1919.

Colonial Office (CO) 648/10 Administration Reports, 1924.

De Silva, M. (2009). Javanese Indentured Labourers in British North Borneo. Phd. Thesis. School of Oriental and African Studies, University of London.

De Silva, M. (Julai 2011). 'Javanese Labour Migrants in British North Borneo, 1914-1932: A Historical Perspective'. BUMANTARA: Journal of Social and Political Development, 1(1), 2341.

De Silva, M. (2011). Perekrutan Buruh Kontrak Jawa ke Borneo Utara: Sejarah Diplomatik antara Syarikat Berpiagam Borneo Utara (SBBU) dan Kerajaan Hindia Timur Belanda 1890-1932, dalam Azlizan Mat Enh Mahmud, Sejarah Diplomatik: Esei-esei penghargaan kepada Prof. Dato' Dr. Nik Anuar Nik Mahmud. Kuala Lumpur: Dewan Bahasa dan Pustaka.

De Silva, M. (2012). 'Wanita di Estet Perladangan: Kajian Kes di Borneo Utara, 1914-1932”. In Azlizan bte. Enh. (ed.). Wanita dan Masyarakat. Universiti Tun Hussein Onn.

De Silva, M. (2019). Buruh Jawa di Borneo Utara: Satu Latar Belakang Sejarah. Dalam Eko Prayitno Joko (ed.). Isu-isu Perburuhan dan Tenaga Kerja Indonesia di Sabah, Malaysia. Universiti Malaysia Sabah.

Ee, J. (Mac, 1961). Chinese Migration to Singapore, 1896-1941. Journal of Southeast Asian History, 2(1), 33-51.

Fernando, M. \& Bulbeck, D. (eds.) (1992). Chinese Economic Activity in Netherlands India: Selected Translations from the Dutch. Singapore: Institute of Southeast Asian Studies.

Geertz, C. (1956). The Social Context of Economic Change: An Indonesian Case Study. J.T., Cambridge Mass.

Hardjono, J.M. (1982). Transmigrasi, Dari Kolonisasi Sampai Swakarsa. Jakarta: Gramedia.

Hill, R.D. \& Voo, M.S. (1990). Occupational and Spatial Mobility in an Overseas Chinese Agricultural Community: The Hakkas of Kudat, Sabah, Malaysia. Sojourn: Journal of Social Issues in Southeast Asia, 5(2): 194-218.

Huff, W.G. The Economic Growth of Singapore: Trade and Development in the Twentieth Century. Cambridge and Singapore: Cambridge University Press. 1994.

Kantoor van Arbeid (KvA). (1929). Dertiende Verslag van de Arbeidsinspectie vooor de Buitengewesten 1928. Weltevreden: Landsdrukkerij.

Kantoor van Arbeid (KvA). (1930). Veertiende Verslag van de Arbeidsinspectie voor de Buitengewesten 1929. Weltevreden: Landsdrukkerij.

Lockard, C.A. (April 1971). The Javanese as Emigrant: Observations on the Development of Javanese Settlement Overseas. Indonesia, 11: 41-62.

Lovegrove, L. (1912). British North Borneo. Journal of the Royal Society of Arts, 60(3099), 545-554. Diakses pada 13 Julai 2021 dari http://www.jstor.org/stable/41340115.

Nield, R. (2012). China's Southernmost Treaty Port. Journal of the Royal Asiatic Society Hong Kong Branch, 52: 63-76. Diakses pada 13 Julai 2021, http://www.jstor.org/stable/23890025.

NBCA 1119 Javanese Labourers Memo RE Recruitment through A.D.E.K. Medan.

Page, M.E. \& Sonnenburg, P.M. (2003). Colonialism: An International, Social, Cultural, and Political Encyclopedia. Volume 1. ABC-CLIO. 
Rhoads, E. (1975). China's Republican Revolution: The Case of Kwangtung, 1895-1913. Harvard East Asian Series 81.

Ritherdon, R. (1920). Dues and Port Charges on Shipping Throughout the World: America, Asia, and Australasia. University of Minnesota. (Digitized: 1 Jul 2013)

Simons, M. (2019). Penny Wong: Passion and Principle. Australia: Black Inc.

Stanford, E. (c.1930). Java-China Japan Lyn (Map Showing Routes Ports of Call and Services of the Java-China Japan Line. London. https://www.raremaps.com/gallery/detail/60188/java-chinajapan-lyn-map-showing-routes-ports-of-call-and-s-stanford

Tregonning, K.G. (1967). Home Port Singapore: A History of Straits Steamship Company Limited 1890-1905. Oxford University.

Tregonning, K.G. (2007). Under Chartered Company Rule, 1881-1946. Republished by Synergy Media. (Previously published in 1965 by Singapore: University of Malaya Press).

Wong, T-K.D. (1999). Chinese Migration to Sabah Before the Second World War. Archipel. 58. L'horizon nousantarien. Mélanges en hommage à Denys Lombard (Volume III). 131-158; https://doi.org/10.3406/arch.1999.3538

Wong, T-K.D. (2004). Historical Sabah: Community and Society. Kota Kinabalu: Natural History Publications (Borneo). 